\title{
Rockfall and Rainfall Correlation in the Anaga Nature Reserve in Tenerife (Canary Islands, Spain)
}

\author{
Sergio Leyva ${ }^{1} \cdot$ Noelia Cruz-Pérez $^{2} \cdot$ Jesica Rodríguez-Martín ${ }^{3} \cdot$ Luka Miklin $^{4} \cdot$ Juan C. Santamarta ${ }^{2}$
}

Received: 22 September 2021 / Accepted: 26 December 2021 / Published online: 8 January 2022

(c) The Author(s) 2022

\begin{abstract}
Rockfalls are frequent and damaging phenomena that occur on steep or vertical slopes, in coastal areas, mountains and along coastal cliff. Water, in different forms, is the most common triggered factor of rockfalls. Consequently, we can consider that precipitation is the most influential factor for slope instabilities and it influences almost all other water parameters. Besides, the specific geology of the Anaga nature reserve in the volcanic island of Tenerife, together with its steep landscape, contributes to the instability of the slopes and frequent rockfalls. Recently, due to climate change and global warming, the annual precipitation/rainfall has declined but the number of heavy storms, associated with intense rainfall and strong winds, events that exceed precipitation thresholds in a brief period has increased which triggers slope movements. This paper describes the analysis of information on rainfall-induced rockfalls in Anaga, Tenerife (Canary Islands), to forecast rock failures of social significance and to improve the capability to respond and emergency decision making. To define reliable thresholds for a certain area, we analized information during the period 2010-2016, reconstructed the rockfall events, and statistically analyzed the historical rainfall conditions that led to landslides. The summary graph correlating precipitation to the probability of occurrence of an event was plotted. Statistical and probability graphs were made with the direct relationship between the number of rockfall events and total rainfall in that period by examining the maximum daily precipitation, not only on the day of the event but up to 3 days before. Hence, the results of this study would serve as a guide for the possible forecasting of rainfall-induced rockfalls, especially for road maintenance services, so that they can be on alert or mobilize the necessary resources in advance depending on the intensity of the expected rainfall.
\end{abstract}

\section{Highlights}

- We have determined the correlation between the probability of occurrence of a rockfall event in a natural reserve (Anaga, island of Tenerife, Canary Islands) and the expected rainfall intensity.

- We have observed the time delay between the occurrence of rainfall and rock falls, corroborated by experience in this area, between the day of the event and the day of the maximum rainfall associated with it.

- We have provided a tool to be used by the Civil Protection and Emergency and Road Maintenance and Conservation Services of the island of Tenerife as part of their management to mobilise the necessary resources or means or to adopt traffic limitations or restrictions depending on the level of alert decreed for adverse meteorological phenomena related to rainfall.

Keywords Rockfalls · Canary Islands · Road services · Geological risks · Rainfall episodes

Juan C. Santamarta

jcsanta@ull.es

1 Universidad Politécnica de Madrid (UPM), College of Forestry and Natural Environment, Madrid, Spain

Departamento de Ingeniería Agraria y del Medio Natural, Universidad de La Laguna (ULL), La Laguna (Tenerife), Spain
3 Departamento Técnicas y Proyectos en Ingeniería y Arquitectura, Universidad de La Laguna (ULL), LaLaguna (Tenerife), Spain

4 Croatian Geological Survey, 10000 Zagreb, Croatia 


\section{Introduction}

Rockfalls are, by definition, a type of landslide involving abrupt downward movement of rock or soil, or both, that detach from steep slopes or cliffs (Highland and Bobrowsky 2008). The falling mass may break on impact, start rolling on steeper slopes, and continue rolling until the terrain flattens. Rockfalls are frequent and damaging phenomena that occur on steep or vertical slopes, in coastal areas, mountains, and along rocky banks of rivers and streams (Langping and Hengxing 2015). The volume of material in a rockfall can vary considerably, from individual rocks or clumps of soil to massive blocks thousands of cubic meters in size (Margottini et al. 2013).

Water, whether it is solid water (ice, snow), whether it is in liquid form such as rain, groundwater, melting ice, etc.; or whether it is water pressure, water energy (undercutting of slopes by natural processes such as streams, rivers, and ocean/sea waves), seismic activity, or anthropogenic activities (burst water pipes, and similar), etc., is the most common cause of rockfalls (Ansari et al. 2015; de Vallejo et al. 2020a, b; Hibert et al. 2011; Hürlimann et al. 1999; Keefer 2002; Mateos et al. 2020; Saroglou 2019; Uchimura et al. 2010; Wieczorek and Jäger 1996).

At regional scales, empirical approaches to forecast the occurrence of rainfall-induced landslides depend on accuracy defining rainfall thresholds. In recent years, several authors have proposed different methods for calculating rainfall thresholds through statistical analysis of empirical triggering rainfall distributions. These methods include cumulative rainfall amount versus rainfall duration, or average rainfall intensity versus rainfall duration. However, these precipitation thresholds include numerous uncertainties that limit their application in early warning systems (Rosi et al. 2020; Melillo et al. 2018; Guzzetti et al. 2020).

The empirical estimation of precipitation thresholds is affected by different uncertainties linked to: (i) the availability of quality information concerning rainfall measurements, with numerous parameters of intensity, duration, daily and even hourly data; (ii) the existence of a good inventory of rockfalls that have occurred, specifically with the date of their occurrence; (iii) the characterization and identification of the rainfall event responsible for the landslide. For this reason, it is difficult to find in the literature case studies with a good definition of the triggering rainfall thresholds. However, we can consider that rainfall is the factor that most influences the instability of the slopes, and it can influence almost all the other water parameters mentioned above (Ayonghe et al. 1999; Contino et al. 2017; Vessia et al. 2020). In addition, there is a great danger from rockfalls triggered by rain, especially on volcanic, unstable slopes (Barbano et al. 2014; Kimura and Kawabata 2015; Smerekanicz et al. 2008). Furthermore, evidence of the major influence of rain was provided in the previous study developed in the island of Tenerife by Jiménez and García-Fernández (2000). The study concluded that there is a correlation, with more than $99 \%$ certainty, between intense rainfall periods and the temporal distribution of local microearthquake activity in Tenerife.

Moreover, climate change poses risks to human and natural systems, and the processes of slope instabilities are part of those risks (Komori et al. 2018; Lollino et al. 2015). The result of climate change and global warming is less rainfall in annual rainfall count, but at the same time there are more severe weather events that exceed precipitation thresholds and trigger slope movements, so there will be an increase in precipitation in concentrated events (Luo et al. 2017; Mateos et al. 2020). Although both factors have an influence, for triggering the mechanisms of soil and rock breakage that move the material on the slopes, exceeding the precipitation thresholds (punctual intense precipitation) is more important than the number of days of rainfall per year (accumulated annual precipitation) (Bello-Rodríguez et al. 2019; Hendrix and Salehyan 2012; Hernández González et al. 2016; Hernandez et al. 2018).

In order to define reliable thresholds for a certain area, we need to reconstruct the rockfall events and statistically analyze the historical rainfall conditions that caused landslides. The data should serve as a guide for the possible prediction of rainfall-induced rock slides.

Rock curtains or other slope covers, protective covers over roadways, retaining walls to prevent rolling or bouncing are used to mitigate unstable slopes. Although rock bolts or other similar types of anchoring are used to stabilize cliffs, some landslides cannot be mitigated, making the importance of predicting failures even greater (Gutiérrez et al. 2010; Mateos et al. 2020). Primarily for the safety of the inhabitants but also for preserving infrastructures such as roads and buildings. (Guzzetti et al. 2007, 2008; Miklin et al. 2016; Peruccacci et al. 2017; Valenzuela et al. 2018, 2019; Vennari et al. 2014).

When it comes to protecting human lives, there can never be sufficient research to ensure safety and prevent catastrophic events. For Gran Canaria and Tenerife (Canary Islands) a research group of the Research Institute for Geohydrological Protection (IRPI) and the Geological Survey of Spain (IGME) analyzed rainfall-induced rockfalls based on CTRL-T algorithm exploiting continuous rainfall measurements, and landslide information (Melillo et al., 2020). Therefore, in this article, we will show a new advance about correlation of rockfall and rainfall events from a historicalstatistical perspective in the area of Anaga, Tenerife. 
Fig. 1 Simplified geological map and cross section of Tenerife showing the main structural and geological units. Source: Modified from (Troll and Carracedo 2016)

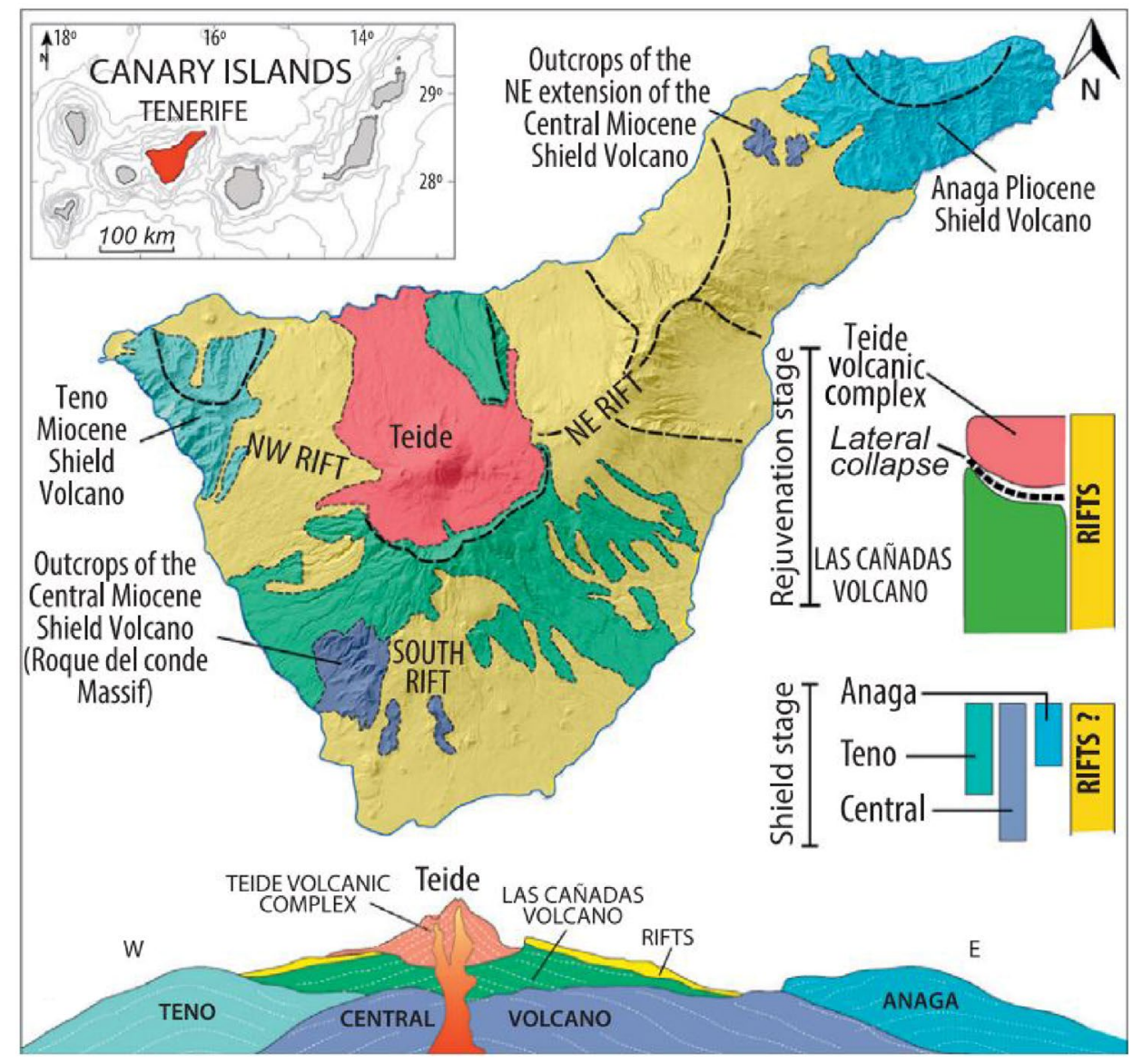

\subsection{Study Area: Anaga, Tenerife (Canary Islands, Spain)}

The Canary archipelago in the Atlantic Ocean consists of eight islands with a total area of about $7500 \mathrm{~km}^{2}$. Tenerife is the largest $\left(2057 \mathrm{~km}^{2}\right)$ and the most populated $(966,000$ inhabitants and 13.2 million visitors in 2019) island in the center of the Canary archipelago (Fig. 1) (data from the Spanish National Statistical Institute).

Tenerife not only occupies a central position within the archipelago but also represents an intermediate evolutionary stage relative to the eastern and the western islands of the island chain. It is home to the third-largest volcano in the world, Pico del Teide. If you take the seafloor as the base of the volcano and not the sea level, then the Teide rises more than $7000 \mathrm{~m}$ in height (3718 masl) (Melillo et al. 2020; Troll and Carracedo 2016).

Tenerife is mainly a basaltic shield, which represents about $90 \%$ of the volume of the island (Hürlimann et al. 1999). It lies on the Jurassic (150-170 Ma) oceanic lithosphere and was constructed via Miocene-Pliocene shields that now form the vertices of the island (Fullea et al. 2015). The shields were unified into a single edifice by later volcanism that continued in central Tenerife from about 12 to 8 million years ago and was followed by a period of dormancy. Rejuvenation at approximately 3.5 Ma is recorded by the central Las Cañadas volcano. During this period magmatic differentiation processes occurred, leading to an episode of felsic and highly explosive felsic volcanism (Fig. 1) (Mart́ and Wolff 2000; Troll and Carracedo 2016).

The Anaga massif belongs to Series I (Middle-Upper Miocene) and, due to erosion, this massif currently has a steep orography (Fig. 2) with steep slopes (Marinonia and Gudmundssonb 2000). The natural reserve of Anaga is a protected area due to its richness in flora and fauna, as well as archaeological sites (Jiménez-Gomis et al. 2019). The orography and altitude favor rainfall in this area of the island, a phenomenon that increases the probability of rock falls in Anaga (Fig. 3).

The Anaga massif has an average altitude of $850 \mathrm{~m}$ above sea level and, in addition, a phenomenon known as the "Foëhn effect" occurs here, which is produced by the warm, humid winds that blow frequently from the northwest to northeast, producing a layer of stratocumulus on the higher ground, often accompanied by drizzle (Santana 2014). Subsequently, the air descends, losing its watery content on the opposite slope. This causes a constant humidity in Anaga, which leads to the capture of horizontal precipitation that 


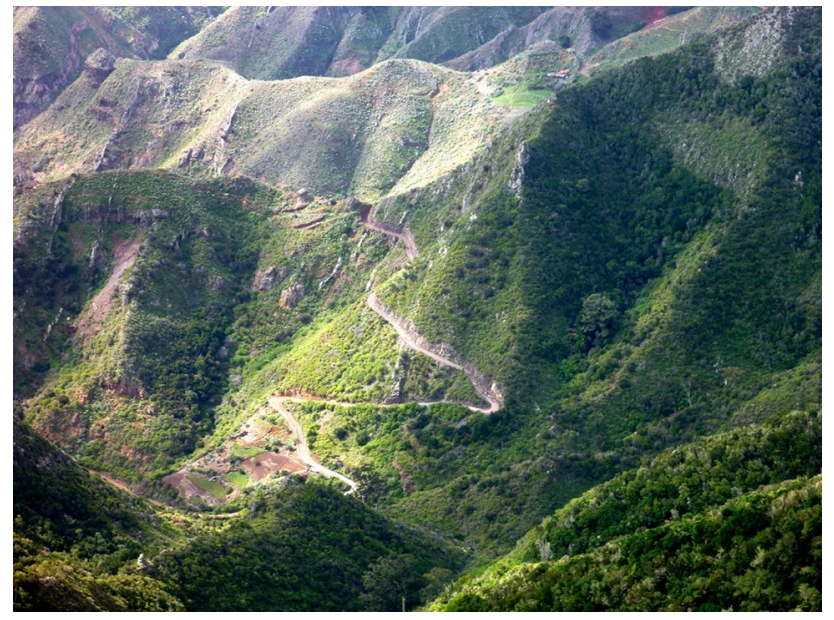

Fig. 2 Steep orography of the Anaga Massif, Tenerife. Source: Juan C. Santamarta

produces the Foëhn phenomenon (Kalivodová et al. 2020). Therefore, the geographical situation of Anaga, located in the northeast of Tenerife, its altitude and the constant humidity on the slopes, make this area of Tenerife one of the areas with the highest rainfall compared to the rest of the island (Diez-Sierra and del Jesus 2020).

High gradient slopes spread over large areas of the islands, and two antagonistic processes are involved in their formation, namely erosion and the formation of lavas, scoria, and pyroclastic layers. Erosion or mass wasting processes occur on previously unstable slopes. Thus, the northern part of the island is characterized by narrow and deep ravines that contribute to intense slope activity (del Potro and Hürlimann 2008; Melillo et al. 2020). Usually, these landscapes are associated with the oldest basaltic outcrops of the islands (along the deep ravines and coastal cliffs of the "Anaga" and "Teno" massifs, the wall of the "Cañadas" caldera, head and edges of the "Güimar" and "La Orotava" valleys in Tenerife
Island) (Fig. 1). In these locations the slopes dip at angles ranging from $50^{\circ}$ to $65^{\circ}$ and from $26^{\circ}$ to $30^{\circ}$ and are nearly vertical in the cliff areas. Most of these areas are the result of earlier landslides and consequently, there is an early occurrence of large mass wasting processes (González de Vallejo et al. 2008; Ledo et al. 2015). The accumulation of volcanic lava flows and interbedded pyroclastic layers is the result of cycles of continuous volcanic eruptions that can result in the the build-up of large steeped edifices with poorly stabilized slopes and high risk of landslides. The growth of such unstable volcanic edifices may occur over previously collapsed areas, filling the resulting deeply eroded depressions prone landslides. Steep slopes created by the accumulation of lavas and pyroclasts are thought to be zones of potential landslide hazard. An example of these steep areas is the "Teide stratovolcano", whose flank inclination varies from $25^{\circ}$ to $30^{\circ}$. Teide has slopes higher than $1000 \mathrm{~m}$ and conditions close to the limit where the slope gradient exceeds the friction angle of their rock massifs (del Potro and Hürlimann 2008; Martí and Wolff 2000; Rodríguez-Losada et al. 2009). These areas can be prone to extremely large landslides if cohesion decreases rapidly. The decrease can be due to shallow magma injection, fluid injection, or groundwater pressure (Herrera and Custodio 2014; Kimura and Kawabata 2015; Rodríguez-Losada et al. 2009). Additional factors such as pre-existing fracture zones also increase the risk of landslides (Hibert et al. 2011).

The steep orography and climatic diversity of Tenerife have resulted in a variety of landscapes and geographical formations. The climate of Tenerife is subtropical oceanic; the minimum and maximum annual average temperatures are about $15{ }^{\circ} \mathrm{C}$ in winter and $24{ }^{\circ} \mathrm{C}$ in summer. The annual rainfall ranges from 100 to $900 \mathrm{~mm}$, being the northern slope the one that receives the highest volume of rainfall, as can be seen from the following image taken from the document CLIMCAN-010 of the Government of the Canary Islands (Fig. 4). Besides, Tenerife offers a wide variety of
Fig. 3 Rockslides after rainfall episodes affecting roads in Anaga, Tenerife. Source: Juan C. Santamarta

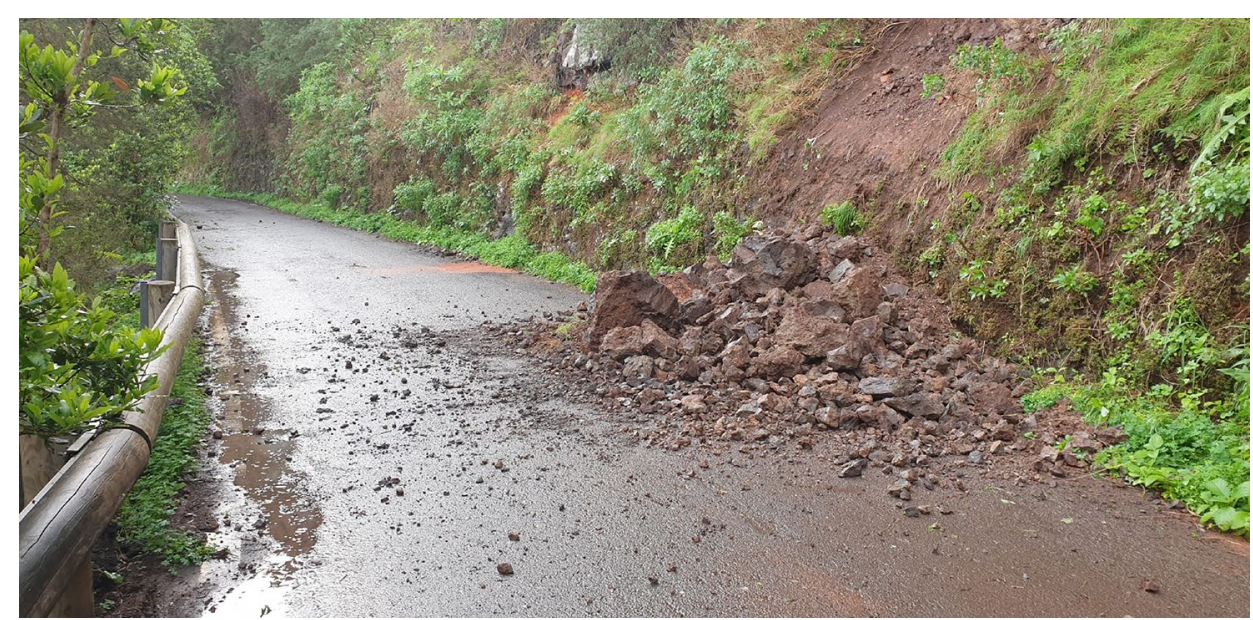


Fig. 4 Climatic characterization of the Canary Islands for the application of the Technical Building Code. Source:Government of the Canary Islands (CLIMCAN-010)

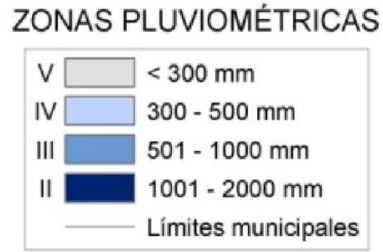

\section{TENERIFE}

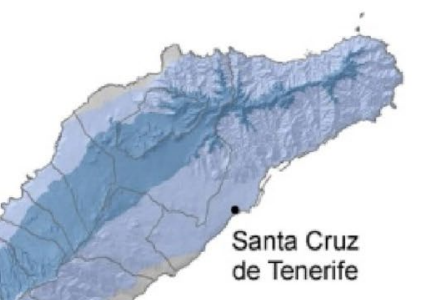

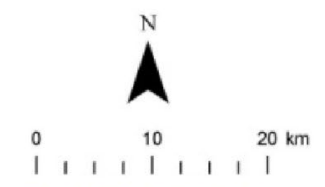

CLIMCAN-010

microclimates controlled by altitude and winds (Bechtel 2016; Hernández González et al. 2016; Köhler et al. 2006).

\section{Methodology}

The methodology followed for data collection was:

1. Collec data on all events classified as "Rockfalls" that occurred during the period 2010-2016 (specifically from $01 / 08 / 2010$ to $05 / 05 / 2016$ ) that were addressed by the personnel assigned to the Contracts of Integral Conservation of Roads (North, South, West and Anaga Sectors), promoted by the Cabildo Insular de Tenerife and conducted by external companies. This information was compiled from the management system implemented in the Organic Unit of Integral Conservation (Cabildo de Tenerife), through the computer application GCC.2 "Gestor de Conservación de Carreteras Versión 2".

2. The representativeness of the data in relation to the totality of the administered roads (Insular and of Regional Interest), a total of $584 \mathrm{kms}$ was included out of the esti-
Table 1 Total kilometers of road in the island of Tenerife

\begin{tabular}{lrl}
\hline Zone & $\mathrm{Km}$ & $\%$ of total \\
\hline Ordinary maintenance & & \\
$\quad$ North & 361 & $26.18 \%$ \\
South & 250 & $18.13 \%$ \\
Center & 183 & $13,31 \%$ \\
Integral conservation & & \\
$\quad$ Anaga & 96 & $6.98 \%$ \\
West & 97 & $7.02 \%$ \\
North & 183 & $13.26 \%$ \\
South & 208 & $15.13 \%$ \\
& 1378 & $100 \%$ \\
\hline
\end{tabular}

mated total of $1378 \mathrm{kms}$ that in that period were available in the entire island (Table 1). However, all the most important main roads of the island (highways, multi-lane roads and conventional roads with the highest traffic) are included; thus, their representativeness of the island's road infrastructure is considered as sufficient.

3. Review of all the reports of incidents collected, checking through the attached graphic information for possible 


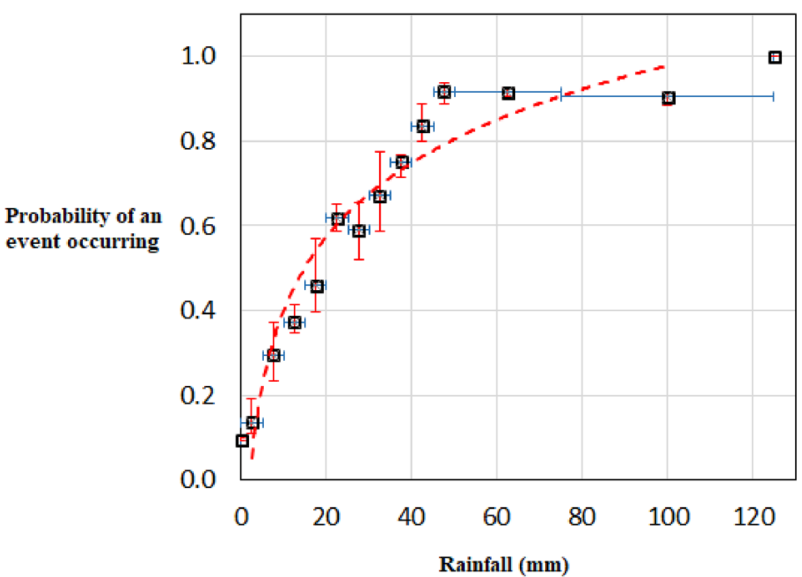

Fig. 5 Probability of an event occurring in Anaga as a function of daily precipitation level together with the corresponding mean and extreme values considering $N=4,3,2$ and 1 day. Source: (González de Vallejo et al. 2020a, b)

errors, as well as the magnitude of the event, discarding for the study those related to very small surface detachments and with no effect on traffic.

4. Compilation of all meteorological data during that period (2010-2016) from all existing raingauges in the study area. The information published by $\mathrm{AEMET}^{1}$ and AgroCabildo $^{2}$ was used, selecting the gauge closest to each incident.

5. Study the relationship between events and precipitation by calculating probabilities. In the case of Anaga Sector, due to previous experience, it was known that there was a certain delay between the day on which the precipitation occurred and the day on which the event occurred. Therefore, the study was done by checking the maximum daily precipitation, not only on the day of the event, but up to 3 days before.

\section{Results and Discussion}

Figure 5 shows the summary graph of the statistical study conducted on the relationship between the daily level of precipitation and landslide events occurring on the roads of the Anaga Sector.

A significant observation is the delay between the day of the event and the day the maximum precipitation occurred,

\footnotetext{
1 http://www.aemet.es/es/portada.

2 http://www.agrocabildo.org/agrometeorologia_estaciones.asp.
}

up to a maximum of 3 days before the event. The results indicate:

- $39 \%$ of the maximum precipitation took place on the day of the landslide;

- $26 \%$ the day before;

- $15 \%$ two days before;

- $20 \%$ three days before.

Therefore, only $40 \%$ of the events seem to be associated with the maximum precipitation occurring on the day of the landslide. This fact corroborates the experience in this Sector, which confirms that after an episode of rainfall of a certain intensity, events tend to occur not only on the same day but also on the following days without new rainfall in most cases.

Figure 6 shows the total number of events in Anaga and the monthly accumulated rainfall. Thus, the results highlight the direct relationship between the number of events and the total amount of rainfall in that period.

The implications of this study can be used in emergency prevention management, especially for road maintenance services, so that they can be on alert or mobilize the necessary resources in advance depending on the intensity of the expected rainfall. In this sense, a graph (Fig. 7) has been prepared for the Anaga Sector, which relates the level of expected rainfall - type of alert with the probability of at least one event occurring on that day. The alert system is similar to the meteorological alert system used by the AEMET (yellow, orange and red levels whose thresholds for Tenerife are 60/100/180 $\mathrm{mm}$ in $12 \mathrm{~h}$ ), with the following results:

- A yellow alert (or pre-alert situation according to the DGSE of the Government of the Canary Islands) indicates the probability of at least one event occurring in the Anaga Sector ranges between 70 and $90 \%$.

- An orange alert indicates a probability ranging between 70 and $90 \%$.

- A red alert indicates a probability of $100 \%$.

\section{Conclusions}

Intense rainfall modifies hydrogeological conditions and water levels. Surface movements, predominantly of soils and altered materials, can be triggered. These movements can include new landslides or debris flows, reactivation of old landslides and rockfalls.

From the analysis of the data, it can be concluded that there is a direct relationship between accumulated rainfall and the occurrence of instabilities. The greatest probability for these events applies to when precipitation is greatest. 


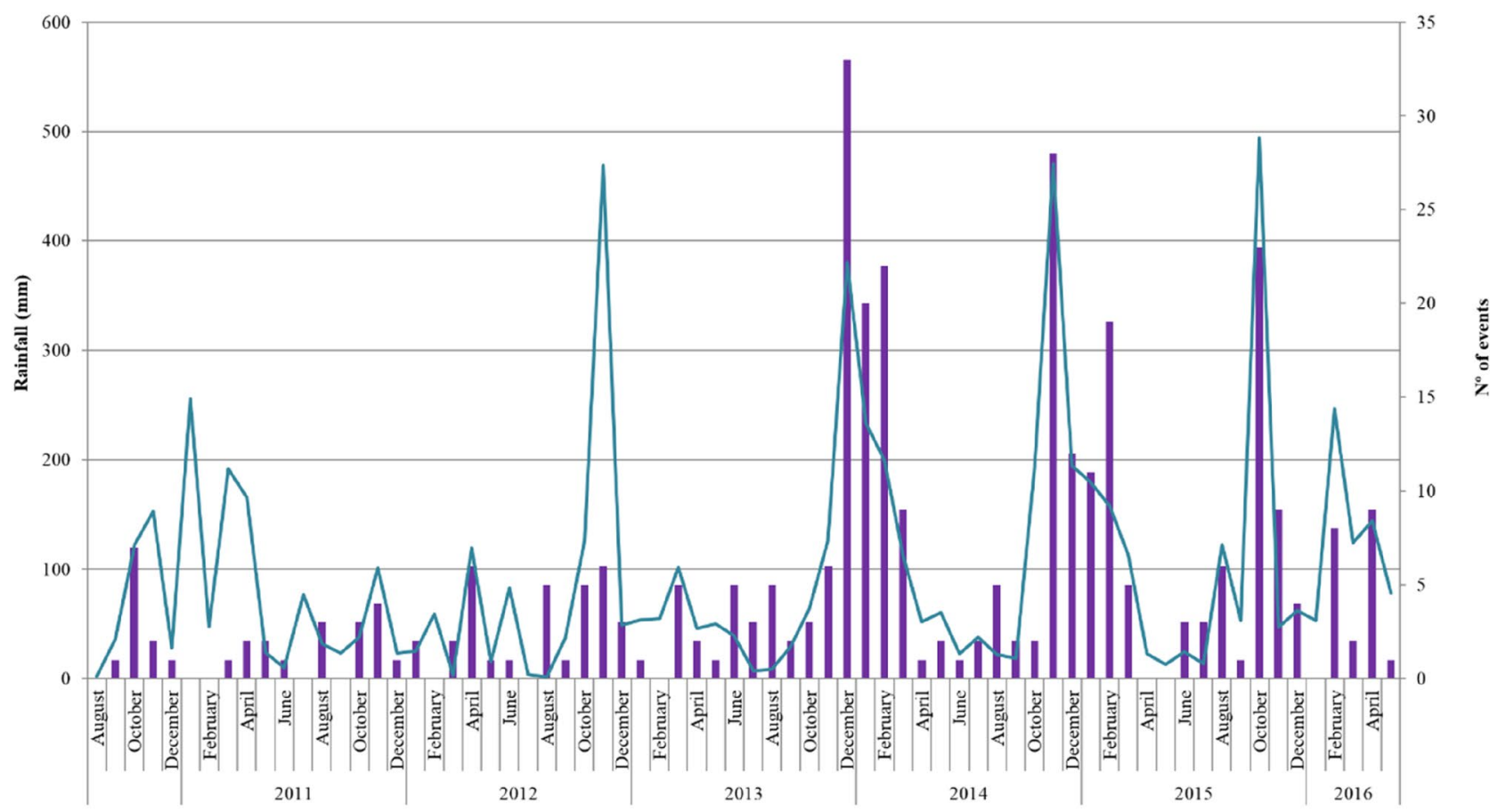

Fig. 6 Number of events related to rainfall events in the Anaga Sector. Observations taken from August 2010 to May 2016. Source: MACASTAB project (González de Vallejo et al. 2020a, b)

Fig. 7 Relationship between precipitation levels, alerts and landslides in the Anaga sector

\section{Relatioship between precipitation levels - alerts - landslides}

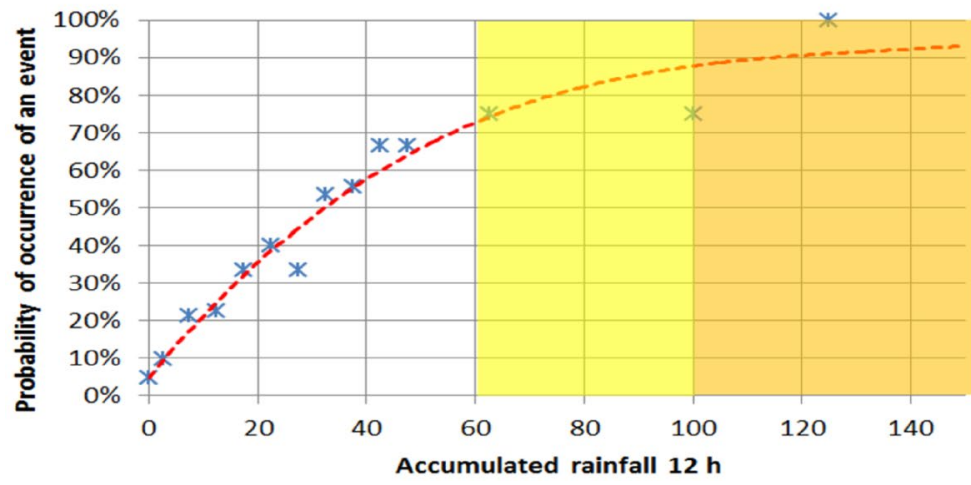

* Probab. event
This relationship can be uses as a predictive tool in emergency management, especially for road maintenance and conservation service. Likewise, it has been possible to verify in a certain Sector that in a relevant percentage, the events do not occur in a rhythmic manner on the same day that the maximum rainfall occurs but until several days later. This circumstance is related to the geomorphology (steep reliefs) and the type of material (strongly altered and weathered on the surface) that makes up the slopes in Anaga area.

Finally, it should be noted that this study has been based on data provided by the Road Conservation Organic Unit. These data apply only to landslides and rockfalls that occur from slopes adjacent to roads the Unit is responsible for and for events assessed by the Unit. Other events may have occurred in this area but may not have affected a road or may not have been assessed by the Unit. Therefore, the values obtained should be considered as a minimum threshold.

Acknowledgements The authors thank the Technical Service of Roads and Landscape of the Island Council of Tenerife for the information and documentation considered in this study. This work has been carried out with the financial support of the Interreg Atlantic Area Programme through the European Regional Development Fund under grant agreement $\mathrm{N}^{\circ}$ EAPA_884/2018 (AGEO project). This contribution reflects only the authors' view and that the European Union is not liable for any use that may be made of the information contained therein. Likewise, we would like to thank the previous work developed by the technical team drafting the MACASTAB Project as well as the University of La 
Laguna for their contribution in relation to the statistical treatment of rainfall and event data.

Funding Open Access funding provided thanks to the CRUE-CSIC agreement with Springer Nature.

Open Access This article is licensed under a Creative Commons Attribution 4.0 International License, which permits use, sharing, adaptation, distribution and reproduction in any medium or format, as long as you give appropriate credit to the original author(s) and the source, provide a link to the Creative Commons licence, and indicate if changes were made. The images or other third party material in this article are included in the article's Creative Commons licence, unless indicated otherwise in a credit line to the material. If material is not included in the article's Creative Commons licence and your intended use is not permitted by statutory regulation or exceeds the permitted use, you will need to obtain permission directly from the copyright holder. To view a copy of this licence, visit http://creativecommons.org/licenses/by/4.0/.

\section{References}

Ansari MK, Ahmed M, Singh R, Singh TN, Ghalayani I (2015) Rainfall, a major cause for rockfall hazard along the roadways, highways and railways on Hilly Terrains in India. In: Lollino G, Manconi A, Clague J, Shan W, Chiarle M (eds) Engineering geology for society and territory, 1. Springer, Cham, pp 457-460. https:// doi.org/10.1007/978-3-319-09300-0

Ayonghe SN, Mafany GT, Ntasin E, Samalang P (1999) Seismically activated swarm of landslides, tension cracks, and a rockfall after heavy rainfall in Bafaka, Cameroon. Nat Hazards 19(1):13-27. https://doi.org/10.1023/A:1008041205256

Barbano MS, Pappalardo G, Pirrotta C, Mineo S (2014) Landslide triggers along volcanic rock slopes in eastern Sicily (Italy). Nat Hazards 73(3):1587-1607. https://doi.org/10.1007/ s11069-014-1160-1

Bechtel B (2016) The climate of the canary Islands by annual cycle parameters. Int Arch Photogramm Remote Sens Spatial Inf Sci 41:243-250. https://doi.org/10.5194/isprsarchi ves-XLI-B8-243-2016

Bello-Rodríguez V, Gómez LA, Fernández López Á, Del-Arco-Aguilar MJ, Hernández-Hernández R, Emerson B, González-Mancebo JM (2019) Short- and long-term effects of fire in subtropical cloud forests on an oceanic island. Land Degrad Dev 30(4):448-458. https://doi.org/10.1002/ldr.3237

Contino A, Bova P, Esposito G, Giuffré I, Monteleone S (2017) Historical analysis of rainfall-triggered rockfalls: the case study of the disaster of the ancient hydrothermal Sclafani Spa (Madonie Mts, northern-central Sicily, Italy) in 1851. Nat Hazards Earth Syst Sci 17(12):2229-2243. https://doi.org/10.5194/nhess-17-2229-2017

del Potro R, Hürlimann M (2008) Geotechnical classification and characterisation of materials for stability analyses of large volcanic slopes. Eng Geol 98(1-2):1-17. https://doi.org/10.1016/j.enggeo. 2007.11.007

Diez-Sierra J, del Jesus M (2020) Long-term rainfall prediction using atmospheric synoptic patterns in semi-arid climates with statistical and machine learning methods. J Hydrol 586:124789. https:// doi.org/10.1016/j.jhydrol.2020.124789

Fullea J, Camacho AG, Negredo AM, Fernández J (2015) The Canary Islands hot spot: new insights from 3D coupled geophysicalpetrological modelling of the lithosphere and uppermost mantle. Earth Planet Sci Lett 409:71-88. https://doi.org/10.1016/j.epsl. 2014.10.038
González de Vallejo LI, Hijazo T, Ferrer M (2008) Engineering geological properties of the volcanic rocks and soils of the Canary Islands. Soils Rocks 31(1):3-13

González de Vallejo LI, Hernández-Gutiérrez LE, Miranda A, Ferrer M (2020a) Rockfall hazard assessment in volcanic regions T. Geosciences (Switzerland) 10(6):1-20. https://doi.org/10.3390/ geosciences 10060220

González de Vallejo LI, Hernández Gutiérrez LE, Miranda A, Ferrer M (2020b) Rockfall hazard assessment in volcanic regions based on ISVS and IRVS geomechanical indices. Geosciences 10:1-20. https://doi.org/10.3390/geosciences 10060220

Gutiérrez F, Lucha P, Galve JP (2010) Reconstructing the geochronological evolution of large landslides by means of the trenching technique in the Yesa Reservoir ( Spanish Pyrenees ). Geomorphology 124(3-4):124-136. https://doi.org/10.1016/j.geomorph. 2010.04.015

Guzzetti F, Rossi M, Nazionale C, Alta M, Stark CP (2007) Rainfall thresholds for the initiation of landslides in Central and Southern Europe. Meteorol Atmos Phys. https://doi.org/10.1007/ s00703-007-0262-7

Guzzetti F, Peruccacci S, Rossi M, Stark CP (2008) The rainfall intensity-duration control of shallow landslides and debris flows: an update. Landslides. https://doi.org/10.1007/s10346-007-0112-1

Guzzetti F, Luigi Gariano S, Peruccacci S, Brunetti M, Marchesini I, Rossi M, Melillo M (2020) Geographical landslide early warning systems. Earth Sci Rev 200:102973. https://doi.org/10.1016/j. earscirev.2019.102973

Hendrix CS, Salehyan I (2012) Climate change, rainfall, and social conflict in Africa. J Peace Res 49(1):35-50. https://doi.org/10. 1177/0022343311426165

Hernandez Y, Guimarães Pereira Â, Barbosa P (2018) Resilient futures of a small island: a participatory approach in Tenerife (Canary Islands) to address climate change. Environ Sci Policy 80(November 2017):28-37. https://doi.org/10.1016/j.envsci.2017.11.008

Hernández González Y, Gimaraes-Pereira Â, Rodríguez González S, Cuevas Agulló E, Barbosa P (2016) Perspectives on contentions about climate change adaptation in the Canary Islands: a case study for Tenerife. European Commission, Joint Research Centre Publications Office. https://data.europa.eu/doi/10.2788/8586

Herrera C, Custodio E (2014) Groundwater flow in a relatively old oceanic volcanic island: the Betancuria area, Fuerteventura Island, Canary Islands, Spain. Sci Total Environ 496:531-550. https://doi. org/10.1016/j.scitotenv.2014.07.063

Hibert C, Mangeney A, Grandjean G, Shapiro NM (2011) Slope instabilities in Dolomieu crater, Réunion Island: from seismic signals to rockfall characteristics. J Geophys Res Earth Surf 116(4):1-18. https://doi.org/10.1029/2011JF002038

Highland LM, Bobrowsky P (2008) The landslide handbook-a guide to understanding landslides. US Geol Surv Circ 1325:1147. https://doi.org/10.3133/cir1325

Hürlimann M, Ledesma A, Martí J (1999) Conditions favouring catastrophic landslides on Tenerife (Canary Islands). Terra Nova 11(2-3):106-111. https://doi.org/10.1046/j.1365-3121.1999. 00233.x

Jiménez MJ, García-Fernández M (2000) Occurence of shallow earthquakes following periods of intense rainfall in Tenerife, Canary Islands. J Volcanol Geotherm Res 103(1-4):463-468. https://doi.org/10.1016/S0377-0273(00)00237-7

Jiménez-Gomis C, García Frank A, Sarmiento Chiesa G, Castillo Ruiz C (2019) Conservation status of the listed marine fossil sites in the Macizo de Anaga biosphere reserve (Tenerife, Canary Islands, Spain). Geoheritage 11(4):1757-1769. https:// doi.org/10.1007/s12371-019-00388-9

Kalivodová H, Culek M, Čermák M, Maděra P, Habrová H (2020) Potential importance of Socotra dragon's blood tree cloud forests and woodlands for capturing horizontal precipitation. 
Rendiconti Lincei 31(3):607-621. https://doi.org/10.1007/ s12210-020-00933-7

Keefer DK (2002). Investigating landslides caused by earthquakesa historical review. U.S. Geological Survey, 345 Middlefield Road MS 977, Menlo Park, CA 94025, USA, 473-510

Kimura J-I, Kawabata H (2015) Geochemistry, geophysics, geosystems. Geochem Geophys Geosyst 16(1):267-300. https://doi. org/10.1002/2014GC005684.Key

Köhler L, Gieger T, Leuschner C (2006) Altitudinal change in soil and foliar nutrient concentrations and in microclimate across the tree line on the subtropical island mountain Mt. Teide (Canary Islands). Flora: Morphol Distrib Funct Ecol Plant 201(3):202214. https://doi.org/10.1016/j.flora.2005.07.003

Komori D, Rangsiwanichpong P, Inoue N, Ono K (2018) Climate risk management distributed probability of slope failure in Thailand under climate change. Clim Risk Manag 20(October 2017):126-137. https://doi.org/10.1016/j.crm.2018.03.002

Langping Li, Hengxing L (2015) Probabilistic modeling of rockfall trajectories: a review. Bull Eng Geol Environ 74:1163-1176. https://doi.org/10.1007/s10064-015-0718-9

Ledo J, Queralt P, Marcuello A, Bellmunt F, Ogaya X, Pérez N (2015) Vertical collapse origin of Las Cañadas caldera (Tenerife, Canary Islands) revealed by 3-D magnetotelluric inversion. Geophys Res Lett 42:1710-1716. https://doi.org/10.1002/ 2015GL063042.Received

Lollino G, Manconi A, Clague J, Shan W, Chiarle M (2015) Engineering geology for society and territory (Climate Ch, Vol. 1). Springer International Publishing, Switzerland

Luo J, Zheng Z, Li T, He S (2017) Spatial heterogeneity of microtopography and its influence on the flow convergence of slopes under different rainfall patterns. J Hydrol 545:88-99. https:// doi.org/10.1016/j.jhydrol.2016.12.018

Margottini C, Canuti P, Sassa K (2013) Landslide science and practice, vol 1. Springer, Heidelberg, New York, Dordrecht, London. https://doi.org/10.1007/978-3-642-31325-7

Marinonia LB, Gudmundssonb A (2000) Dykes, faults and palaeostresses in the Teno and Anaga massifs of Tenerife (Canary Islands). J Volcanol Geotherm Res 103:83-103. https://doi.org/ 10.1016/S0377-0273(00)00217-1

Martí J, Wolff JA (2000) Introduction: the geology and geophysics of Tenerife. J Volcanol Geotherm Res 103(1-4):7-10. https:// doi.org/10.1016/s0377-0273(00)00213-4

Mateos RM, López-Vinielles J, Poyiadji E, Tsagkas D, Sheehy M, Hadjicharalambous K, Liscák P, Podolski L, Laskowicz I, Iadanza C, Gauert C, Todorović S, Auflič MJ, Maftei R, Hermanns RL, Kociu A, Sandić C, Mauter R, Sarro R et al (2020) Integration of landslide hazard into urban planning across Europe. Landsc Urban Plan. https://doi.org/10.1016/j.landurbplan.2019.103740

Melillo M, Brunetti M, Peruccacci S, Gariano S, Roccati A, Guzzetti F (2018) A tool for the automatic calculation of rainfall thresholds for landslide occurrence. Environ Model Softw 105:230-243. https://doi.org/10.1016/j.envsoft.2018.03.024

Melillo M, Gariano SL, Peruccacci S, Sarro R, Mateos RM, Brunetti MT (2020) Rainfall and rockfalls in the Canary Islands: assessing a seasonal link. Nat Hazards Earth Syst Sci 20(8):2307-2317. https://doi.org/10.5194/nhess-20-2307-2020

Miklin Z, Urumović K, Terzić J, Halamić J, Novosel T (2016) Engineering geological model of landslide Dragodan. Zbornik Na Trudovi - Knjiga 1. In: Lepitkova S, Boev B (eds) Struga : Makedonsko Geološko Društvo, pp 229-237. https://www.bib.irb.hr/ 857775

Peruccacci S, Brunetti MT, Gariano SL, Melillo M (2017) Geomorphology rainfall thresholds for possible landslide occurrence in
Italy. Geomorphology 290:39-57. https://doi.org/10.1016/j.geomo rph.2017.03.031

Rodríguez-Losada JA, Hernández-Gutiérrez LE, Olalla C, Perucho A, Serrano A, Eff-Darwich A (2009) Geomechanical parameters of intact rocks and rock masses from the Canary Islands: implications on their flank stability. J Volcanol Geotherm Res 182(12):67-75. https://doi.org/10.1016/j.jvolgeores.2009.01.032

Rosi A, Segoni S, Canavesi V, Monni A, Gallucci A, Casagli N (2020) Definition of 3D rainfall thresholds to increase operative landslide early warning system performances. Landslides 18(3):1045-1057. https://doi.org/10.1007/s10346-020-01523-2

Santana LM (2014) Estudio climático sucinto de anaga. Cabildo de Tenerife. https://www.agrocabildo.org/publica/analisisclimatico/ ANAGA_SUCINTO.pdf

Saroglou C (2019) GIS-based rockfall susceptibility zoning in Greece. Geosciences (Switzerland). https://doi.org/10.3390/geoscience s9040163

Smerekanicz J, Peter C, Ingraham P, Brandon H, Hee P, Ferdinand M, Cajigal P, Journeaux D (2008) Rock slope stabilization measures at the Pali tunnel route 30, Maui, Hawai'i. In: 58 th Highway Geology Symposium (HGS) [online]. Santa Fe: New Mexico Department of Transportation \& New Mexico Bureau of Geology and Mineral Resources, pp 142-153. http://www.highwaygeo logysymposium.org/wp-content/uploads/59_HGS-r-OPT.pdf

Troll VR, Carracedo JC (2016) The geology of tenerife 5. Elsevier, Amsterdam. https://doi.org/10.1016/B978-0-12-809663-5. 00005-0

Uchimura T, Towhata I, Anh TTL, Fukuda J, Bautista CJB, Wang L, Seko I, Uchida T, Matsuoka A, Ito Y, Onda Y, Iwagami S, Kim MS, Sakai N (2010) Simple monitoring method for precaution of landslides watching tilting and water contents on slopes surface. Landslides 7(3):351-357. https://doi.org/10.1007/ s10346-009-0178-z

Valenzuela P, José IM, Antonio DIM, García M (2018) Rainfall thresholds for the triggering of landslides considering previous soil moisture conditions ( Asturias, NW Spain). Landslides. https:// doi.org/10.1007/s10346-017-0878-8

Valenzuela P, Zêzere JL, Domínguez-cuesta MJ, Antonio M, García M (2019) Empirical rainfall thresholds for the triggering of landslides in Asturias (NW Spain). Landslides 16:1285-1300. https:// doi.org/10.1007/s10346-019-01170-2

Vennari C, Gariano SL, Antronico L, Brunetti MT, Iovine G, Peruccacci S, Terranova O, Irpi CNR, Alta M, Università P (2014) Rainfall thresholds for shallow landslide occurrence in Calabria, southern Italy. Nat Hazards Earth Syst Sci 14:317-330. https:// doi.org/10.5194/nhess-14-317-2014

Vessia G, Di Curzio D, Chiaudani A, Rusi S (2020) Regional rainfall threshold maps drawn through multivariate geostatistical techniques for shallow landslide hazard zonation. Sci Total Environ 705:135815. https://doi.org/10.1016/j.scitotenv.2019.135815

Wieczorek GF, Jäger S (1996) Triggering mechanisms and depositional rates of postglacial slope- movement processes in the Yosemite Valley, California. Geomorphology 15:17-31. https://doi.org/10. 1016/0169-555X(95)00112-I

Publisher's Note Springer Nature remains neutral with regard to jurisdictional claims in published maps and institutional affiliations. 